\title{
GENDER STEREOTYPES IN THE PROFESSIONAL APPROACH OF SOCIAL WORKERS IN SLOVAKIA, THE CZECH REPUBLIC AND LITHUANIA Júlia Fričová ${ }^{1}$, Lenka Štefáková ${ }^{2}$, Katarína Kohútová $^{3}$
}

\begin{abstract}
Background and Objectives: Gender stereotypes and the conventionalization of terms like motherhood and fatherhood have, of lately, been a subject of heated debated and have been a dichotomizing theme for the society. A fraction of the population recognizes the allotment of the model role of a mother, as the caregiver and homemaker, and that of a father, as the caretaker and breadwinner, while the other segment of people oppose this allocation of functions and responsibilities. These circumstances, in turn, influence diverse domains of the society's operations, in addition to social workers whose clientele merely consists of fathers and mothers.

Main Goal: The central purpose of the study is to juxtapose and discern the prevalence of stereotyped gender depictions, representing the ideal role expected and presumped from men and women, within families of social workers in Slovakia, the Czech Republic and Lithuania.

Methods: The primary method used for producing this research was that of pragmatic analysis and detailed evaluation of derivative secondary data which aided in the formulation of conclusions for the study regarding the topic in concern. Investigative results of the three studies, were obtained and refined by charatceristic and subjective approaches - such as interviews and content analysis. The total number of participants were 28 (13 Slovak, 7 Czech, 8 Lithuanian).

Results: The results of research display that social workers have gender stereotypes about mothers-carers and fathersbreadwinners, which reflects in their preference for usually choosing to involve women to work with, while confronting family matters, rather than men. However, according to them, this choice only seems natural, functional and habitual as per their practical experience in everyday life. Further revelations included a lack of knowledge, education and awareness on the part of social workers in context of gender equality.

Future Research: Presently, the concept of gender equality in the field of social work has not been adequately studied, and thus, as a matter of fact, the subject offers numerous possibilities and a wide scope for empirical research to be carried out. For future purposes, we suggest examining the issue in one of the advanced, post-industrial or 'developed' countries, the public of which does not identify itself with gender stereotypes, much unlike that of the traditional or 'developing' countries. We believe that the rational and sensible way of reflection of 'developed' countries can contribute in the disintegration and breakdown of the deep-rooted stereotypical mindsets of social workers.
\end{abstract}

UDC Classification: 305-055.1, 305-055.2, DOI: https://doi.org/10.12955/pss.v1.47

Keywords: Gender. Social Worker. Social Work. Social Role. Stereotype.

\section{Introduction}

"Human Beings invent and sustain various social relationships and connections throughout their lifetime. They engage in multiple social interactions within their own realm and surroundings. All mutually interconnected social relations are organized and structured into a proper framework, a civilised arrangement", as stated by Almašiová (2012).

"An integral element of this structure is social status, which represents a specific dignified social position or reputation earned or obtained by a human within the social structure", as mentioned by Scott (2014). Particular social statuses are expected to follow and act in a distinct sophisticated kind of behaviour adjusted to the situation as a component of what is designated as a social role.

Ritzer (2020) defined this social role as "a universal, widespread, general expectation from people who hold a given reputation or status", while Strieženec (1996, p.187) clarified that under these suppositions, there is an understanding of a set of "needs, objectives, views, feelings, attitudes, values and activities". These explanations thus defined social role, image or prestige as a collection of tasks and mannerisms expected by the community from an individual status holder.

Psychologists, Košta (2004) and Newman (2020), acknowledged that social role, is not only a selection consisting of ettiquettes and habitual customs, but it also involves internalized and accomplished activities along with the much envisioned behavioural manifestations. Košta (2004), further went on to say that while this social role is exhibited, the presumpted can differ substantially

\footnotetext{
${ }^{1}$ Catholic University in Ružomberok, Faculty of Education, Department of Social Work, julia.fricova801@edu.ku.sk

${ }^{2}$ Catholic University in Ružomberok, Faculty of Education, Department of Social Work, lenka.stefakova@ku.sk

${ }^{3}$ Catholic University in Ružomberok, Faculty of Education, Department of Social Work, katarina.kohutova@ku.sk
} 
from the conceived behaviour, which devises a certain degree of variation in role behavior without violating role regulations. Deviations can also occur when the same role is executed by two different entities, for example, disparate ways of two mothers in the upbringing of children, or when the same role is executed by the same subject on separate occasions, for example, a mother's difference in attitude towards her second child in comparison to her third.

A notion of social dispute or tension, pertaining to a social role, is described by Košta (2004, p. 53) as "a situation when a person encounters mutually contradicting and incongruous social role demands to be conducted by him/her, and he/she has to distinguish between an inside-role conflict and a betweenrole conflict". An inside-role conflict can be interpreted as a case when discordant expectations clash reciprocally within the same role, whereas a between-role conflict portrays the clash by way of implementing two or more roles simultaneously.

Throughout human life, there is a continuous series of transformations in respect to performing social roles or more precisely, it is observed that these roles are carried out contemporarily. The author, Almašiová (2012), considers three social roles to be of the utmost significance:

- Parental Role: It is very likely that a person may already prepare for the parental role since childhood. This role can be executed by consciously recognising, observing, comprehending and imitating the behaviour of the parents, as well as by acquiring their habits, values, ways of upbringing, etc. Mastery and command over this role is not only important for an individual, but also for the entire society. As Špániková (2013) confessed, "the troubled family in question becomes capable in instilling Principles of Basal, or in other words, the fundamentals of model cultural patterns while raising children, only on a limited basis". This becomes an arduous undertaking when dealing with family members as clients, since it is tough to minimize disagreements between the family and the institution.

- Working Role: This role is strongly associated to every individual's ability to participate in the work cycle. It also includes deciding the profession, preparing for occupational efficiency and employment itself, which later becomes an integral part of a person's human identity.

- Sexual Role: This role involves imposing numerous conditions on both men and women. When we look closely at this role, it appears to be similar to the developing of the parental role, more commonly in a family environment. The idea of a sexual role equates with the idea of assigning special attributes to genders, which generally denotes the social aspect given to genders. Harris and White (2018) observed that this theory was akin to socio-cultural qualities ascribed to men and women within the sphere of the application of socialization processes, which are linked to the disparities between them. Furthermore, this referred to gender stereotypes that implied the classic differences in attitudes, emotions and behaviour, for example, the typical comprehension of women as carers and men as breadwinners. However, Ryle (2020) explains that the existence of these socially built conceptions do not mean that they compulsorily impact the lifestyle of individuals.

According to Hudecová (2017), "the identity of a female, in traditional family models, is generally based on childcare and household activities, whereas that of males is based on being a carrier and having a paid job to support the family". This conventional arrangement of the sex-role is extensive mostly in traditional societies as evident in research carried out in 2017 (Chart 1). Among the handpicked eight Central European countries, the established perception is the most concentrated in Slovakia (51\%), followed by the Czech Republic (47\%) and Poland (40\%). Lesser acceptance is reflected by the public of Austria (30\%), Croatia (26\%), Slovenia (20\%), Switzerland (17\%) and Germany (14\%).

A parallel study called Gender Equality was carried out in the same year by the European Commission within all the member countries of the EU. Alluding to Slovakia, $73 \%$ of interviewees agreed with the statement that "The most important role of a woman is to take care of her home and family" (refer to Chart 2), and thus, it got ranked seventh place. Slovakia was followed by Lithuania, ranking the sixth place (73\%), Latvia, ranking the fifth (74\%), and the subsequent Czech Republic, Poland (77\%), Hungary $(78 \%)$ and Bulgaria $(81 \%)$. On the other hand, the lowest level of approval with this statement was expressed by the people of Holland (15\%), Denmark (14\%) and Sweden (11\%). 

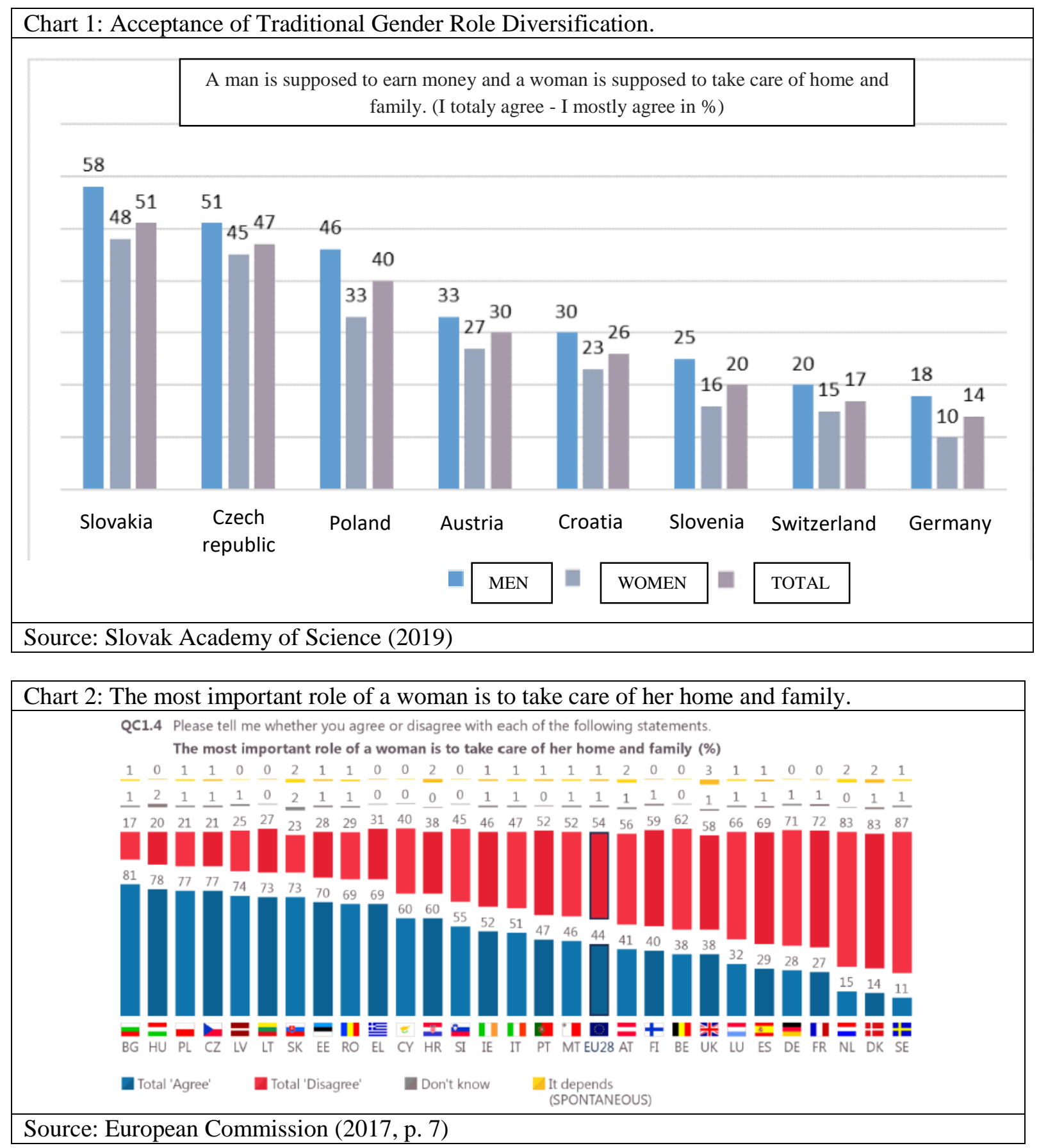

The highest level of agreement with the statement that "The most important role of a man is to earn money" (refer to Chart 3), was demonstrated by the citizens of Bulgaria (81\%), accompanied by Hungary (79\%), Slovakia (75\%) and the Czech Republic (72\%). Disagreement with this statement was shown most by the populations of Holland (83\%), Denmark (80\%) and Sweden (88\%).

The aforementioned research regarding preconceived notions related to genders, proves that these are exceptionally prevalent in traditional societies, mainly Central European countries, and the 'developed' post-industrial countries are in marked contrast with them, as they share the opinion that both men and women have the right to accept both/either of the roles without any ignominy.

\section{Results}

Traditional social work can be classified as an important forum to address, communicate and interact with professional social workers, which as per Rigel and Dastlík (2006, p. 20), "overlooks the gender perspective and avoids dealing with variations in gender relations in the society, but instead depends on conservative values, morals or ethics, for example, the main goal of traditional social work may be 
protecting and sustaining the family as it would entirely adhere to the concept that a complete family is the perfect paradigm in order to achieve the right upbringing".

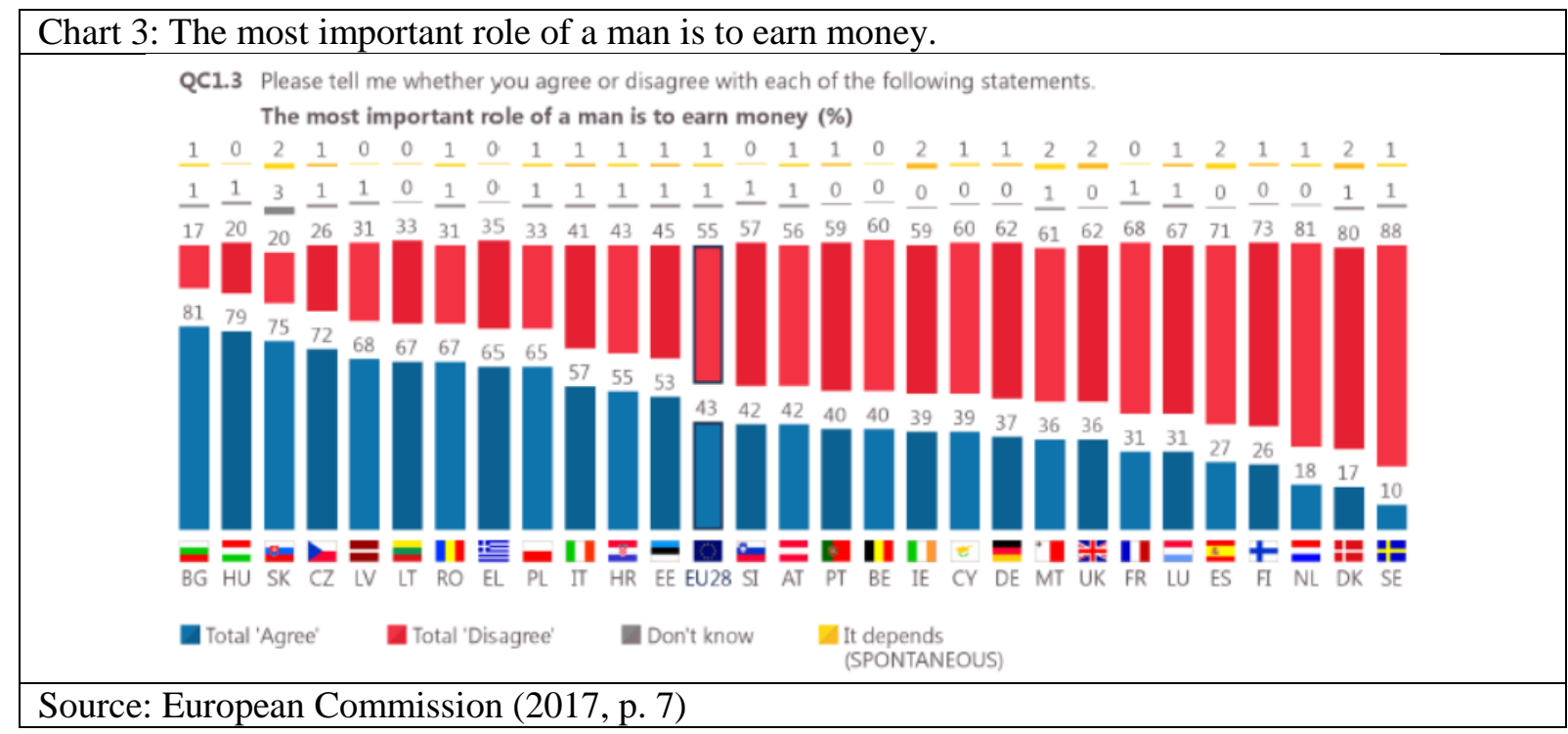

From a feministic viewpoint, traditional social work connotes either gender-neutral clarifications or typecasting of the female role. Conversely, there are two categories within present-day social work founded on feministic principles, that offer gender-sensitive approach, namely, emancipatory and gender-specific social work. According to Janebová (2005), the aim of emancipatory social work is women's consolidation into the egalitarian society by enhancing their self-esteem, confidence, freedom and autonomy, in addition to a mitigation of power gaps between sexes, as well as an eradication or alleviation of repercussions related to gender socialization, which instruct women to be more relationship-oriented than independent. Whilst implementing the gender-specified method, the social worker "should have knowledge of the various aspects of gender socialization, of the ethics, morals, values, standards and principles of womanhood and manhood, should be engrossed in unjust power distribution between men and women. They should also contribute to change the unequal power distribution" (Janebová, 2005, p. 94).

Which crucial element affects the concept of gender-sensitivity and gender stereotypes utilized in the professional approach of a social workers? The Czech study has revealed interesting findings. The main objective of the research has been to answer the question: "How both male and female social workers emphasize on the significance of their male and female clients' gender and how this consideration influences their clientele's professional performance or efficiency" (Gřundělová, 2018).

The investigation sample comprised of 7 social workers (2 men and 5 women) employed in "institutions providing precautionary social activation, field or outpatient services for families with children, of whose growth and development might be at the risk of being compromised as a result of a condition of long-term or chronic social crisis, which cannot be overcome by parents themselves without assistance" (Act No. 108/2006 Coll., about social services, §65, Paragraph. 1). As concerns the selection of the research sample, it is unfeasible to extrapolate standard conclusions relevant for all social workers. The study intended to "determine the circumstances and situations in which the event or process occurs, to find connections between such events, and at the same time, to highlight the issues that have been neglected" (Gavora, In Gřundělová, 2018, p. 45).

The author acquired the research data by way of interviews with social workers and interventional inspections when they were executing their jobs with parents or children, in their natural family environment. The results are summarized in Table 1.

Mothers are usually described by social workers as "caregivers, vivacious, emotional or sympathetic, frivolous, having sophisticated manners, responsible, careful, enduring, tolerant, having an inferior position in the family hierarchy, perceived as helpless or dependent, burdened with childcare and household, etc. Nevertheless, they are also considered as efficient, skilful, clever, resolute and determined to solve unfavourable family situation" (Gřundělová, 2018, p. 48). 


\begin{tabular}{|} 
Table 1: Role Construction of Mother and Father, Created by Both Male and Female Social Workers \\
\hline Mothers & Fathers \\
\hline main clients & marginal clients \\
\hline carer & breadwinner \\
\hline responsible & irresponsible \\
\hline need help & do not need/want help \\
\hline active & passive \\
\hline present & absent \\
\hline communicative & non-communicative \\
\hline obedient & disobedient \\
\hline emotional & not emotional \\
\hline helpless & able to help themselves \\
\hline burdened with care & independent \\
\hline source of problem shooting & a cause of problems \\
\hline irrational & rational \\
\hline a victim & a threat \\
\hline Source: Grundělová (2018, p. 48) & \\
\hline
\end{tabular}

In comparison, fathers are described as "family breadwinners, independent, rational or pragmatic, authoritative, having addictions of addictive substance or alcohol, receive social benefits or are privileged, aggressive (perpetrators of domestic violence), non-communicative, controlling or dominating their wives, but are themselves controlled by their mothers" (Gřundělová, 2018, p. 48).

Survey findings point to advertent and inadvertent speculations, biases and prejudices of social workers towards maternal and paternal roles. They plainly typecast mothers as carers and fathers as breadwinners. The fact that social workers cooperate more with mothers, plays a very interesting part while providing information, as the workers would then basically know family problems from the mother-client's point of view, resulting in a misleading or falsified form of family assistance given. Social workers also confess that they often ignore fathers as parents and perceive them as the troublemakers or aggressors. When commenting, the respondents reflected and contemplated on their routine experience. They believe that the differentiation between mothers and fathers is reasonable, practical and valid (Grunundělová, 2018, p. 48).

These results highlight "the unexplored scope and untapped potential for social work educators who can facilitate anti- oppressive and gender- sensitive procedures" in social work. This can indeed contribute in the prevention and elimination of role stereotypes in the professional performance of social workers (Gřundělová, 2018, p. 49).

A somewhat similar research, targeting the gender- sensitive approach was carried out in the Slovak Republic in 2011. 13 respondents (7 women, 6 men) participated. They worked alongside asylum seekers at the Migration Authority of the Ministry of Interior of the Slovak Republic, the Slovak Humanitarian Council, in the presence of the HRL (Human Rights League) accompanied by Goodwill. The required data was obtained through an open-end questionnaire and was thereafter subjected to quantitative and qualitative analysis (Marková and Zábojníková, 2011).

As indicated by the responses of interviewees, it goes without saying that they had a difficult time grasping the concept of gender-sensitivity, as they were unable to explain it by themselves and were unaware of the specifications of the social work for asylum seekers. The approach's characteristics were classified as "reviewing and examining the differences between men and women" or as "respect and awareness of the culture and traditions of asylum seekers". Nonetheless, a majority of respondents mentioned adopting and complying to the gender-sensitive approach in their professional behaviour, but these responses are deemed worthless owing to the fact that they don't understand the idea itself. This can be confirmed in the way they answer a question related to how they apply the concept whilst working with asylum seekers, to which they give replies like (Table 2): "by tolerating their indigenous culture and introducing them to a new one", "by accepting indigenous cultural gender statuses" and "through woman-to-woman communication", which signifies that female social workers should majorly deal with female asylum seekers.

Scrutinizing the above data, it was revealed that the respondents had an inadvertently common practice of having gender stereotypes towards their asylum seeker clients. Refer to Table 3. 


\begin{tabular}{l}
\hline Table 2: The Way of Gender- Sensitive Approach Implementation \\
\begin{tabular}{|l|c|c|c|}
\hline Reply Categories & Men & Women & Total \\
\hline $\begin{array}{l}\text { Tolerance of Indigenous Culture and Introduction to a New } \\
\text { One }\end{array}$ & 2 & 2 & 4 \\
\hline Acceptance of Indigenous Cultural Gender Positions & 2 & - & 2 \\
\hline Woman-to-Woman Communication & - & 1 & 1 \\
\hline Cooperation and Reciprocity & - & 1 & 1 \\
\hline Did Not Understand the Question & 2 & & 2 \\
\hline Did Not State & - & 3 & 3 \\
\hline
\end{tabular}
\end{tabular}

Source: Marková and Zábojníková (2011,p. 282)

\begin{tabular}{|l|c|c|c|}
\hline \multicolumn{2}{|l|}{} & Women & Total \\
\hline $\begin{array}{l}\text { The Following Thesis Was Supported within the } \\
\text { Professional Assistance for Male/Female Asylum } \\
\text { Seekers: }\end{array}$ & Men & 5 & 9 \\
\hline $\begin{array}{l}\text { Natural Character of Being a Mother (for a Female } \\
\text { Asylum Seeker) }\end{array}$ & 4 & 2 & 4 \\
\hline A Woman is Able to Take Better Care Than a Man & 2 & 1 & 2 \\
\hline $\begin{array}{l}\text { Economic Dependence of a Woman (a Female Asylum } \\
\text { Seeker) }\end{array}$ & 1 & 4 & 5 \\
\hline $\begin{array}{l}\text { Perception of Male Asylum Seeker to be the Head of the } \\
\text { Family }\end{array}$ & 1 & 2 & 5 \\
\hline $\begin{array}{l}\text { Perception of Male Asylum Seeker to be the Children's } \\
\text { Educator }\end{array}$ & 3 & 3 & 7 \\
\hline $\begin{array}{l}\text { Perception of Male Asylum Seeker to be the Family } \\
\text { Breadwinner }\end{array}$ & & & \\
\hline
\end{tabular}

Source: Marková and Zábojníková (2011, p. 283)

Both the research results, the Czech as well as the Slovak ones, concentrate on the existence of gender stereotypes in the professional approach of social workers, implying that male and female social workers confide more in the conventional theory of social work, since they do not realize the essentiality and significance of distinguishing a client's gender or of having a gender-sensitive approach in their workplace. Based on their general practical experience, they point out that gender stereotypes were rather helpful and effective when giving assistance to families, not objectionable.

It is, thus clearly evident that social worker, irrespective of their gender, suffer from a lack of information relating to gender-sensitivity. This statement offers valuable insights on how social work educators can encourage and promulgate anti-oppressive and gender-sensitive approaches.

The most recent study which we dealt with in the text, was implemented by Pivoriene and Bardauskiene, in 2014, in Lithuania. The objective of their research was to recognize the strategy that social workers applied in order to cultivate gender equality at work with socially risky families. The research involved 8 social workers employed at public institutions, non-governmental organizations as well as state institutions, and whose experience ranged between 1.5 years to 6 years.

The authors observe that Lithuanian legislation and national programs offering equal opportunities for women and men, ensure gender equality in politics, employment, education or scientific activity, but leave out, for instance, the division of responsibilities in the household and childcare arena. In Lithuania, the patriarchal concept of family is still fairly powerful and a woman is considered to be a mother, caretaker and defender of the family, or a tutor and educator (Burvyte \& Ralys In Pivoriene \& Bardauskiene, 2016).

When working with socially risky families, social workers frequently encounter the traditional stereotyped categories of the roles of the mother as the carer and the father as the breadwinner. Introduction on the subject of gender equality in the family should, therefore, be fueled by making efforts to men men in household chores and childcare, which was also acknowledged by the interviewees in their statements: "Parenting, raising children and eductional activities are a collective responsibility of both parents, where both participate equally" (Pivoriene a Bardauskiene, 2016, p. 4). 
However, social workers themselves concede that during family mediation they are unable to efficiently apply the principles of gender equality in the mother-father relationship, because it is an enduring or long-term process founded on a bilateral give-and-take relationship or mutual communication, tolerance, respect and understanding of the significance and essence of gender equality. In their deliberations, they therefore, undertake already deep-rooted stereotypes and divisions of distinct roles in a family.

Moreover, some respondents exclaimed that the issue of gender equality was not applicable for them and that there was no such complication in their work, whereas, concurrently, they draw attention to the deficient information, awareness, education and knowledge they face in this particular field, along with the absence of the indespensible techniques and equipment for its practice. According to the research mentioned before, Czech and Lithuanian social workers admit that in the course of their work with socially risky families, their primary focus is the mother, as "a woman has to carry everything on her shoulders" and "we demand too much from women, still men must also be involved" (Pivoriene a Bardauskiene, 2016, p. 5).

\section{Conclusion}

Stereotyping or pigeonholing is present in the human way of thinking, and leads to the production and cultivation of simplified judgements, usually associated with certain kinds of emotional experiences (Vybíral, 2000). According to Atkinson (1995), a stereotype is "a judgement summary regarding personal features or physical characteristics of a group of people", which may prove to be misleading in social interactions. The stereotypical understanding of men and women is currently prevalent in traditional societies, as indicated by the results of the study called Gender Equality. It was conducted by the European Commission within all member states of the EU in 2017. The results showed that in traditional countries (for example: Bulgaria, Poland, the Czech Republic, Slovakia etc.), men were supposed to earn money and have the role of the breadwinner. Contrastingly, women were meant to take care of children and look after the household. This perception of male and female social status influenced the professional performance of social workers. This point has been proved in the Czech research that focused on social workers assigned alongside families with children in the social activation service institutions (Gřundělová, 2018), the Slovak research, carried out in the realm of the social work for asylum seekers (Marková and Zábojníková, 2011), and the Lithuanian research, carried out among social workers working with families at social risk (Pivoriene and Bardauskiene, 2016). The Czech research results imply that social workers cooperate with mothers and fathers, based on stereotyped patterns, such as that of the mother as the carer and of the father as the breadwinner. The result was that there was an inclination of more intensive cooperation with mothers, whereas fathers were involved in the intervention only marginally, leading to impoverishment of provided assistance to family, besides poor mutual communication. Anyhow, when answering the questionnaire, social workers relied on their daily routine practice and considered their professional approach to be original and effective. There were similar results from the Lithuanian research, in which social workers confessed of working more with mothers, rarely involving fathers in the interventions. However, this is not a consequence of their own gender stereotypes, but the effect of stereotypes and the division of roles, which have been repeatedly used in families over the years. Some also agreed on the need to introduce gender equality into the mother-father relationship, but others viewed the issue of gender equality in the family to be irrelevant and unnecessary in realtion to the performance of their work.

Another analogous study conducted among social workers for asylum seekers has revealed powerful stereotyping and the deprivation of gender-sensitivity towards their clients, asylum seekers. Moreover, it was established that social workers have inadequate knowledge in reference to this issue which is clearly evident in their definition of gender-sensitive approach, as "knowledge and respect of indigenous culture and traditions of asylum seekers".

Strengths and Limitations

In the text provided, we have compared the occurence of gender stereotyped images related to the role of men and women in a family, during the professional performance of social workers. For elaboration, we examined and investigated secondary data, which happened to compose the results of the three researches focused on the given issue. 
As concerns the contribution of the submitted text, we reckon that the topic chosen had validity and needed to be bought into spotlight in order to raise awareness on gender equality for the new generation of social workers, who shouuld constantly keep expanding their knowledge and skills, and thus, contribute to improving the quality of life for their clients.

Regarding limitations, we reflect that there is a lack in research data, and therefore, there is the possibility of generalizing the obtained results for all social workers. On the other hand, this limitation can be considered as an opportunity to carry out further empirical research, which would add on to the enrichment of scientific knowledge and would increase the quality of productive efficiency of social workers.

\section{Recommendations}

As mentioned above, we would like to suggest identical research material such as, a study in one of the 'developed' post-industrial countries, of whose population has not been recognized with traditional gender stereotypes, but support the view that women and men can perform multiple roles simultaneously, regardless of their affiliation to a given sex or genus. In addition to this, we would also like to highlight the inadequacy of pragmatic, empirical interest in the context of this topic with respect to the socio-cultural conditions of the Slovak Republic. Based on the acquired information, we futher recommend improvement in the extension or spread of knowledge and education regarding gender-sesitivity and anti-oppressive approach to social workers. Furthermore, we consider the general dissemination of awareness and education on gender equality in society, whether by means of mass media or through the educational process in schools, to be just as crucial.

\section{References}

Almašiová, A. (2012). Sociológia. [Sociology] Ružomberok: VERBUM.

Atkinsonová, R. L. (1996). Psychologie. [Psychology] Praha: Victoria Publishing.

Baum, N. (2016). The Unheard Gender: The Neglect of Men as Social Work Clients. British Journal of Social Work, 14631471.

European Commission. (2017). Gender Equality 2017. Gender Equality, Stereotypes and Women in Politics. Retrieved 03 10, 2020, from

https://ec.europa.eu/commfrontoffice/publicopinion/index.cfm/Survey/getSurveyDetail/yearFrom/1974/yearTo/2019/survey $\mathrm{Ky} / 2154 / \mathrm{p} / 2$

Gřundělová, B. (2018). Kritická reflexe konstrukce mateřství a otcovství v sociální práci s rodinou. [Critical reflection on the construction of motherhood and fatherhood in social work with the family] In Sociální práce/Sociálna práca(3), 40-51.

Harris, J., \& White, V. (2018). Dictionary of Social Work \& Social Care. Oxford: Oxford Univerity Press.

Janebová, B. (2005). Otázky moderní feministické sociální práce: Emancipatorní, nebo genderově specifická sociální práce? [Questions of modern feminist social work: Emancipatory or gender-specific social work?] In Sociální práce/Sociálna práca(3), 86-98.

Košta, J. (2004). Sociológia. [Sociology] Bratislava: Ekonóm.

Marková, D., and Zábojníková, M. (2011). Rodové stereotypy v sociálnej práci s azylantkami. [Gender stereotypes in social work with refugees] Humanum. Międzynarodowe Studia Społeczno-Humanistyczne(7), 275-287.

Newman, B. M., \& Newman, P. R. (2020). Theories of Adolescent Development. Massachusetts: Elsevier Academic Press.

Pivoriene, J., \& Bardauskiene, R. (2016). Social Work with Families at Social Risk Promoting Gender Equality. SHS Web of Conferences, 30, 00024. https://doi.org/10.1051/shsconf/20163000024.

Riglová, A., \& Dastlík, L. (2006). Přispěvky k genderově senzitivni sociální práci s ženami azylantkami. [Contributions to gender-sensitive social work with women refugees] Retrieved 03 10, 2020, from https://adoc.tips/pispvky-k-genderovsenzitivni-socialni-praci-s-enami-azylant.html

Ritzer, G. (2020). Essentials of Sociology (Fourth ed.). University of Maryland.

Ryle, R. R. (2020). Questioning Gender: A Sociological Exploration. California: SAGE Publishing.

Scott, J. (2014). A Dictionary of Sociology. Oxford: Oxford University Press.

Slovenská akadémia vied. (2019). Tradičné delenie rodových roli u nás stále pretrváva. [Traditional division of gender roles still persists in our country] Retrieved 03 10, 2020, from https://www.sav.sk/index.php?lang=sk\&doc=servicesnews\&source_no=20\&news_no $=8130$

Strieženec, Š. (1996). Slovník sociálneho pracovnika. [Social worker dictionary] Trnava: AD.

Špániková, M. (2013). Väzenský systém v Estónsku. [Prison system in Estonia] In: Sociálna práca, manažment a ekonómia prínosy a limity vedy pre teóriu a prax. Ružomberok: VERBUM - vydavatel'stvo Katolíckej univerzity v Ružomberku.

Vybíral, Z. (2000). Psychologie lidské komunikace. [Psychology of human communication] Praha: Portál.

Zákon č. 108/2006 Sb. o sociálních službách. (2006). 